This manuscript was published in Animal Production Science.

Nogueira, D.M., Gummow, B., Gardiner, C.P., Cavalieri, J., Fitzpatrick, L.A., Parker, A.J., 2016b. A survey of the meat goat industry in Queensland and New South Wales. 2. Herd management, reproductive performance and animal health. Animal Production Science 56, 1533-1544, 2016.

\title{
A Survey of the Meat Goat Industry in Queensland and New South Wales. 2. Herd management, reproductive performance and animal health
}

\author{
D.M. Nogueira ${ }^{A, B^{*}}$, B. Gummow ${ }^{B, C}$, C.P. Gardiner ${ }^{B}$, J. $_{\text {Cavalieri }}^{B}$, \\ L.A. Fitzpatrick ${ }^{B}$ and A.J. Parker ${ }^{B}$
}

${ }^{\text {A } E m b r a p a ~ S e m i a ́ r i d o, ~ B R ~ 428, ~ K m ~ 142 . ~ C a i x a ~ P o s t a l ~ 23 . ~ C E P ~ 56300-972, ~ P e t r o l i n a, ~ P E, ~ B r a z i l . ~}$

${ }^{\text {B }}$ School of Veterinary and Biomedical Sciences, James Cook University, Townsville, QLD 4811, Australia.

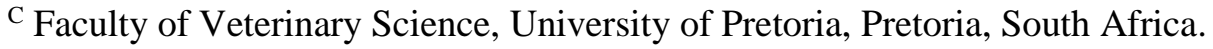

*Corresponding author. Email: daniel.nogueira@embrapa.br

\begin{abstract}
An interview based questionnaire survey was conducted on 31 goat properties in New South Wales (NSW) and Queensland (QLD) in 2013. This study has gathered information on goat herd management, reproductive performance and animal health, and has identified constraints that may limit goat productivity. Producers from high rainfall regions reported having full blood Boer goats for stud breeding. In contrast, producers from pastoral regions had rangeland goats and Boer-cross goats. Overall, 87\% of the producers identified a natural breeding season in goats and $61 \%$ separated kids from their mothers at weaning. The weaning age varied between 3.0 to 6.0 months. A total of $52 \%$ of producers castrated male kids. Only $10 \%$ of producers used ultrasound to conduct pregnancy diagnosis on their goats. The reported pregnancy rate was $60 \%$ for the Pastoral regions and $94 \%$ for the High rain fall regions. The average prolificacy was 1.4 kids/doe and the kidding interval was 12 months. Overall, 68\% of producers fed their goat herd with supplements, with the exception that most producers from western NSW and southwestern QLD did not use supplements. Producers considered gastrointestinal parasites (61\%) and body lice (48\%) as the main diseases associated with their goat herds, although only $52 \%$ mentioned drenching the animals with anthelmintics. In general, properties in the pastoral regions showed low pregnancy and kidding rates, early age at first mating,
\end{abstract}


high mortality rates, poor performance of Boer bucks and lower weights and weight gain than properties in the high rainfall regions. The survey has highlighted areas that require further study to validate the observations of producers, for instance, factors that may be limiting the fertility of Boer goats in rangeland environments, the incidence of diseases, the use of Kidplan ${ }^{\circledR}$ and management strategies to improve goat productivity.

Additional keywords: goatmeat, diseases, feral goats, rangeland.

\section{Introduction}

The economic importance of the goat industry is increasing around the world and this dynamic sector may prove to be a new lever for agricultural development in the $21 \mathrm{st}$ century (Boyazoglu et al. 2005). Australia is the largest exporter of goat meat worldwide, exporting 31,700 tonnes of meat and 75,100 live goats in 2013-14 (McRae and Thomas 2014). Meat goat exports from Australia were initiated in 1952 (Restall et al. 1982), but producers in the pastoral regions are still conducting opportunist harvesting of goats and they keep few records related to their property (Nogueira et al., 2015). According to Brice et al. (2012) little is known about goat production systems and productivity of rangeland goat meat enterprises in Australia.

The goat herd in Queensland is estimated to represent $12.3 \%$ of the national goat herd while the New South Wales herd represents $73.8 \%$, and together these two states represent $86.1 \%$ of the national goat herd in Australia, with other states and territories making up the remaining goat numbers (Pople and Froese 2012). A survey of the meat goat industry in Victoria, Australia, showed that the three main animal health issues identified by commercial goat producers were: internal parasitism, low fertility and Johnes disease; and the three main animal husbandry issues identified were: kid predation, fencing security and kid growth rates (Ferrier and McGregor 2002).

Previous studies on goat heath showed that the prevalence of lymphadenitis in Western Australia was 7.8\% (Batey et al. 1986); enterotoxaemia throughout Australia was $1.4 \%$ (Uzal et al. 1998), caprine arthritis encephalitis in New South Wales was 59.7\% (Greenwood et al. 1995) and coccidiosis in South Australia was 97\% for the domestic goats and 3\% for feral goats (O'Callaghan 1989). However, little data appears to be available regarding goat enterprises, animal health and reproductive performance within Queensland and New South Wales. For this reason, a study was designed to survey farmers' knowledge and practices on the herd management, which includes timing of the breeding season, kidding, weaning, culling and selection, animal health, nutrition and 
genotypes utilised by meat goat producing enterprises within Queensland and New South Wales. A companion paper to this publication has discussed the management of pastures, stocking rates and markets of meat goat producing enterprises (Nogueira et al., 2015).

\section{Material and Methods}

\section{Survey design and structure}

An interview based questionnaire survey was conducted on goat properties located in Queensland (QLD) and New South Wales (NSW) during 2013. The questions were related to the period 2012 to 2013. The questionnaire consisted of 106 questions and was designed to take an average of 2.5 hours to be completed. The majority of the questions were in a multiple tick-a-box format, which were modified from a previous beef industry survey reported by Bortolussi et al. (2005a).

The survey was conducted via face to face interviews where one or two authors visited meat goat producers and completed the questionnaire with them. Goat producers were the owners of properties that derived substantial income from meat goats. Face to face interviews ensured a consistent approach and interpretation of the questions and high response rate. The template questionnaire and methodology for this survey was approved by the Human Ethics Committee of James Cook University (approval number: ID H4415).

\section{Survey validation}

To manage the quality of data collected, most survey questions were crossreferenced where responses to a particular question could be cross-checked and/or validated by the response to a previous or subsequent question (Bortolussi et al. 2005b). In addition, there were some follow up calls or emails after the survey was conducted for clarification of responses. The questionnaire was tested with four producers prior to the survey and a revised questionnaire was then used with the wider survey group. On most properties, an inspection of pasture and herd management was conducted with the authorization and presence of the owner. Inspection of the pastures and herd validated some the responses provided in the questionnaire. 


\section{Survey population}

The survey was carried out in Queensland and New South Wales, and involved owners of 31 properties that derived income from goats. Meat goat producers were recruited non-randomly through direct approach and local networks. The sample frame comprised farmers listed by the respective state government extension personnel, the investigators personal contacts and the Australian Boer Goats Breeders Association. The producers were screened to include only commercial private goat producers and corporate companies. Those willing to participate in the survey were then included. The first contact with producers was done either by telephone or email when the purpose of the survey was explained. Seventy-four percent (31/42) of goat producers approached were willing to participate in the survey. Taking part in the survey was voluntary. They formed six clusters representing the major goat producing areas in Queensland and New South Wales (Fig. 1). The properties were clustered according to proximity and labelled as regions 1 to 6 (Table 1).

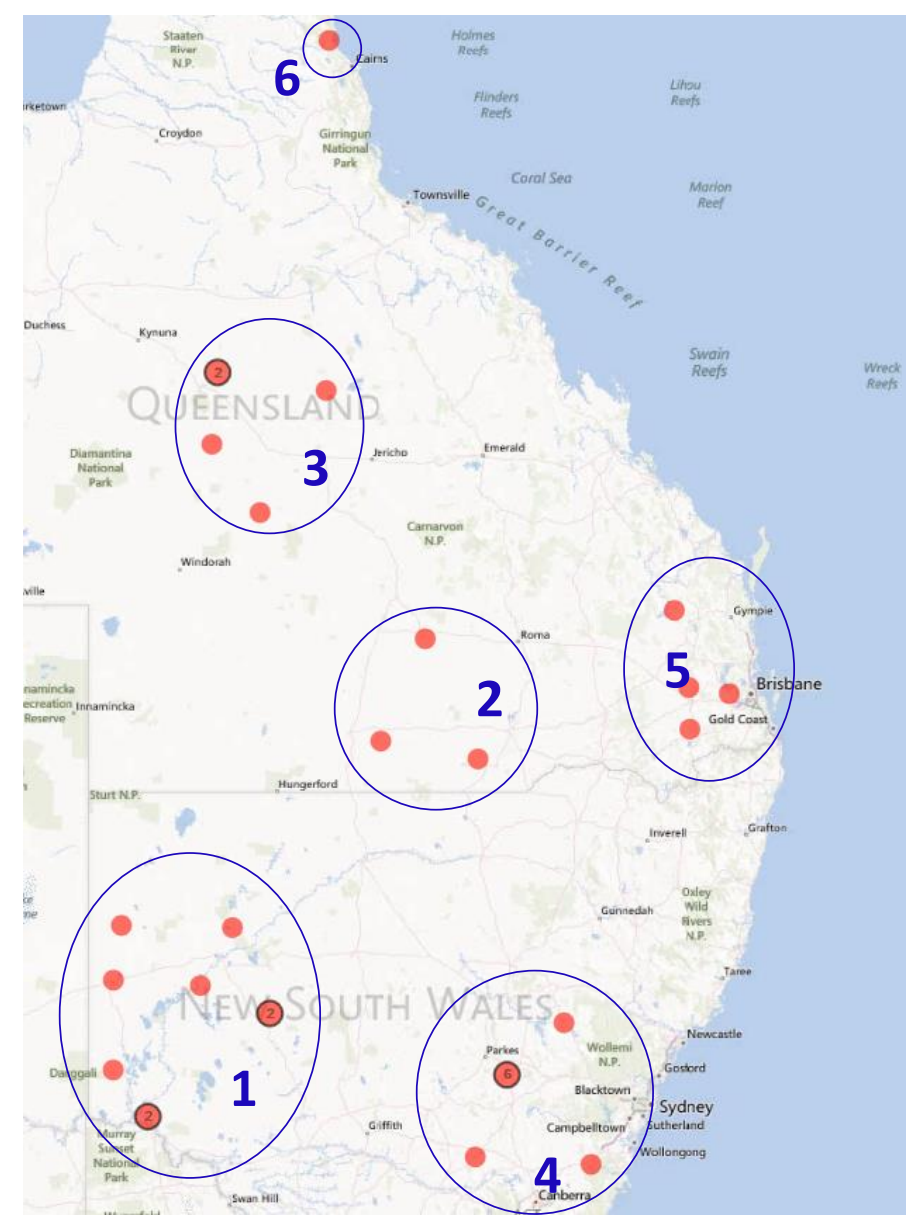


Fig. 1. Location of properties included in the survey, which were clustered in three pastoral regions (1,2 and 3) and three high rainfall regions (4, 5 and 6) of Queensland and New South Wales.

Table 1. Brief description of the surveyed regions in Queensland and New South Wales adapted from the Interim Biogeographic Regionalisation for Australia.

\begin{tabular}{|c|c|c|c|c|c|c|}
\hline Region & $\begin{array}{c}\text { Bioregion } \\
\text { (predominant) }\end{array}$ & $\begin{array}{l}\text { Towns } \\
\text { closest to } \\
\text { survey sites }\end{array}$ & $\begin{array}{l}\text { Annual } \\
\text { Rainfall } \\
\text { (range) }\end{array}$ & $\begin{array}{l}\text { Temperature } \\
\text { (average } \\
\text { max and } \\
\text { min) } \\
\end{array}$ & $\begin{array}{c}\text { Altitude } \\
\text { (above } \\
\text { sea } \\
\text { level) } \\
\end{array}$ & $\begin{array}{l}\text { Climate } \\
\text { (Köppen) }\end{array}$ \\
\hline $\begin{array}{c}1 . \\
\text { Western } \\
\text { NSW }\end{array}$ & $\begin{array}{l}\text { Broken Hill } \\
\text { Complex }\end{array}$ & $\begin{array}{c}\text { Broken Hill, } \\
\text { Mildura, } \\
\text { Wilcannia }\end{array}$ & $\begin{array}{l}130 \mathrm{~mm} \\
\text { to } 250 \\
\text { mm. }\end{array}$ & $\begin{array}{l}\text { Summer: } \\
34^{\circ} \mathrm{C} \\
\text { Winter: } 5^{\circ} \mathrm{C}\end{array}$ & $\begin{array}{l}94 \mathrm{~m} \text { to } \\
315 \mathrm{~m}\end{array}$ & $\begin{array}{l}\text { Hot desert } \\
\text { climate. }\end{array}$ \\
\hline $\begin{array}{c}2 . \\
\text { South- } \\
\text { western } \\
\text { QLD }\end{array}$ & Mulga Lands & $\begin{array}{l}\text { Dirranbandi, } \\
\text { Morven, } \\
\text { Charleville }\end{array}$ & $\begin{array}{l}500 \\
\mathrm{~mm} .\end{array}$ & $\begin{array}{l}\text { Summer: } \\
35^{\circ} \mathrm{C} \\
\text { Winter: } \\
18^{\circ} \mathrm{C}\end{array}$ & $\begin{array}{l}170 \mathrm{~m} \\
\text { to } \\
290 \mathrm{~m}\end{array}$ & $\begin{array}{l}\text { Hot, dry, } \\
\text { semi-arid } \\
\text { climate }\end{array}$ \\
\hline $\begin{array}{c}3 . \\
\text { Central- } \\
\text { western } \\
\text { QLD }\end{array}$ & $\begin{array}{c}\text { Mitchell } \\
\text { Grass Downs }\end{array}$ & $\begin{array}{l}\text { Corfield, } \\
\text { Longreach, } \\
\text { Isisford }\end{array}$ & $\begin{array}{l}250 \mathrm{~mm} \\
\text { to } 500 \\
\mathrm{~mm}\end{array}$ & $\begin{array}{l}\text { Summer: } \\
38^{\circ} \mathrm{C} \\
\text { Winter: } \\
12^{\circ} \mathrm{C} \text {. }\end{array}$ & $\begin{array}{l}191 \mathrm{~m} \\
\text { to } \\
203 \mathrm{~m}\end{array}$ & $\begin{array}{c}\text { Dry } \\
\text { monsoonal } \\
\text { to semi-arid } \\
\text { climate }\end{array}$ \\
\hline $\begin{array}{c}4 . \\
\text { Eastern } \\
\text { NSW }\end{array}$ & $\begin{array}{c}\text { South-western } \\
\text { Slopes }\end{array}$ & $\begin{array}{c}\text { Forbes, } \\
\text { Mudgee, } \\
\text { Cootamundra }\end{array}$ & $\begin{array}{l}600 \mathrm{~mm} \\
\text { to } 750 \\
\mathrm{~mm} .\end{array}$ & $\begin{array}{l}\text { Summer: } \\
28^{\circ} \mathrm{C} \\
\text { Winter: } 2^{\circ} \mathrm{C}\end{array}$ & $\begin{array}{l}240 \mathrm{~m} \\
\text { to } \\
320 \mathrm{~m}\end{array}$ & $\begin{array}{l}\text { Humid, } \\
\text { high } \\
\text { rainfall, } \\
\text { temperate } \\
\text { climate and } \\
\text { hot } \\
\text { summers }\end{array}$ \\
\hline $\begin{array}{l}5 . \\
\text { South- } \\
\text { eastern } \\
\text { QLD }\end{array}$ & South-eastern & $\begin{array}{c}\text { Wivenhoe } \\
\text { Pocket, } \\
\text { Toowoomba, } \\
\text { Proston }\end{array}$ & $\begin{array}{l}700 \mathrm{~mm} \\
\text { to } 944 \\
\mathrm{~mm}\end{array}$ & $\begin{array}{l}\text { Summer: } \\
23^{\circ} \mathrm{C} \\
\text { Winter: } 9^{\circ} \mathrm{C}\end{array}$ & $\begin{array}{l}458 \mathrm{~m} \\
\text { to } \\
691 \mathrm{~m}\end{array}$ & $\begin{array}{c}\text { Subtropical } \\
\text { highland } \\
\text { with warm } \\
\text { summers } \\
\text { and cool } \\
\text { winters }\end{array}$ \\
\hline $\begin{array}{c}6 . \\
\text { Far } \\
\text { North } \\
\text { QLD }\end{array}$ & Wet Tropics & Mossman & $\begin{array}{l}2,010 \\
\mathrm{~mm}\end{array}$ & $\begin{array}{l}\text { Summer: } \\
28^{\circ} \mathrm{C} \\
\text { Winter: } \\
20^{\circ} \mathrm{C}\end{array}$ & $4 \mathrm{~m}$ & $\begin{array}{l}\text { Tropical } \\
\text { monsoon } \\
\text { climate } \\
\text { with } \\
\text { summer } \\
\text { wet season }\end{array}$ \\
\hline
\end{tabular}

Source: Adapted from the Interim Biogeographic Regionalisation for Australia (IBRA 2014).

\section{Definition of terms and parameters evaluated}

'Pastoral regions' refers to properties located in western NSW and western QLD

(Regions 1, 2 and 3), characterised as an arid environment (130 $\mathrm{mm}$ to $500 \mathrm{~mm}$ rainfall). 
Livestock production from pasture (extensive grazing) is the main source of farm income. 'High rainfall regions' refers to properties located in the eastern NSW, eastern QLD and far north QLD (Regions 4, 5, and 6), with an annual rainfall of more than $600 \mathrm{~mm}$. These properties are smaller, and livestock is raised under an intensive grazing management system. 'Does' refers to female goats; 'bucks' are male goats; 'kids' are newborns or young goats; 'maidens' are young female goats and 'wethers' are castrated male goats. 'Pregnancy rate' was defined as the number of does that were pregnant/ total number of exposed does; 'kidding interval' was the period between two parturitions; 'prolificacy' was calculated as the number of kids born/ number of kidding does. The 'kidding rate' was calculated by (number of kids in the herd/ number of exposed does) x 100. 'Breeding season' was considered as the natural period where does regularly enter oestrus and are mated with bucks. 'Mortality rate' was the number of dead goats/ number of goats born. 'Full Blood' refers to Boer goats originated from fully imported bloodlines and pedigrees can be traced back to South Africa herd books. 'Kidplan ${ }^{\circledR}$ ' is an Australian database developed to select animals using estimated breeding values (EBVs) and customised selection indices that help producers and breeders assess their genetic potential (Ball et al. 2001). 'Estimated weight gain at weaning (g/day)' was calculated by subtracting the bodyweight at birth from that at weaning and then dividing by the age at weaning (days).

\section{Data analysis}

Data were analyzed using Epi Info software (Epi Info ${ }^{\mathrm{TM}}$ 7.1.1.14, USA, 2013). Descriptive statistical procedures were used to compare surveyed regions. Data is presented as mean and standard deviation, frequencies and cross-tabulation tables. Overall percentages were calculated by the number of properties in both pastoral and high rainfall regions showing the characteristics divided by total number of properties $(n=31)$ and multiplied by 100 . The data expressed as percentages were compared using the Chisquare test. Differences were considered significant when $\mathrm{P}<0.05$.

\section{Results}

\section{Records from goat production}

The questionnaire survey found that properties located in the pastoral regions had few records on animal performance. In general, only seedstock producers and commercial breeders kept records on goat production and information about goat management. 
Overall, 97\% (30/31) of producers reported keeping stock records. However, the two records they kept were the 'stock numbers' (97\%; 30/31) and records from 'sales or kill sheets' (87\%; 27/31; Table 2).

\section{Goat breeds and body weight}

Producers reported the existence of the following breeds: Australian rangeland goats, Boer (White and Red), Anglo-Nubian, Toggenburg, Saanen and Savannah. All the properties located in the pastoral regions had rangeland goats and Boer-cross goats, while properties located in the high rainfall regions had full blood Boer goats for stud breeding. Breeds other than rangeland and Boer goats were kept by 35\% (11/31) of producers interviewed. Producers reported introducing Boer goats into the rangeland goat herd to improve body and carcass weights. However, some goat producers from rangeland environments reported a lack of satisfaction with the use of Boer bucks on their properties. These producers stated that full blood male Boer goats had a poor reproductive performance when crossed with their rangeland doe herds. Only 35\% of producers evaluated the body condition score of the animals and this was usually a casual evaluation as "Good" or "Bad". The pastoral regions recorded lower live weights for mature (3-yearold) breeding does and bucks compared to the high rainfall regions (Table 3). 
Table 2. Records kept by goat producers in New South Wales and Queensland from 2012 to 2103

\begin{tabular}{|c|c|c|c|c|c|c|c|c|c|}
\hline \multirow[b]{2}{*}{ Stock records } & \multicolumn{3}{|c|}{ Pastoral regions } & \multirow[b]{2}{*}{$\begin{array}{c}\text { Subtotal } \\
n\end{array}$} & \multicolumn{3}{|c|}{ High rainfall regions } & \multirow[b]{2}{*}{$\begin{array}{c}\text { Subtotal } \\
\mathrm{n}\end{array}$} & \multirow[b]{2}{*}{$\begin{array}{c}\text { Overall } \\
\mathrm{n}(\%)\end{array}$} \\
\hline & $\begin{array}{l}\text { West } \\
\text { NSW }\end{array}$ & $\begin{array}{c}\text { S.West } \\
\text { QLD }\end{array}$ & $\begin{array}{l}\text { C.West } \\
\text { QLD }\end{array}$ & & $\begin{array}{c}\text { East } \\
\text { NSW }\end{array}$ & $\begin{array}{l}\text { S.East } \\
\text { QLD }\end{array}$ & $\begin{array}{l}\text { North } \\
\text { QLD }\end{array}$ & & \\
\hline Number of properties & 9 & 3 & 5 & 17 & 9 & 4 & 1 & 14 & $31(100)$ \\
\hline Kept records and stock numbers & 8 & 3 & 5 & 16 & 9 & 4 & 1 & 14 & $30(97)$ \\
\hline Sales or kill sheets & 8 & 3 & 4 & 15 & 8 & 3 & 1 & 12 & $27(87)$ \\
\hline Births & 1 & 2 & 3 & 6 & 9 & 4 & 1 & 14 & $20(65)$ \\
\hline Paddocks record* & 5 & 1 & 4 & 10 & 4 & 3 & 1 & 8 & $18(58)$ \\
\hline Deaths & 0 & 1 & 2 & 3 & 9 & 4 & 1 & 14 & $17(55)$ \\
\hline Supplementary feeding & 0 & 1 & 1 & 2 & 5 & 4 & 1 & 10 & $12(39)$ \\
\hline Pregnancy status & 0 & 0 & 0 & 0 & 6 & 0 & 2 & 8 & $8(26)$ \\
\hline Treatment to diseases & 0 & 0 & 0 & 0 & 5 & 2 & 1 & 8 & $8(26)$ \\
\hline
\end{tabular}

$*$ Use of fertilizer, sowing grasses or legumes or pulling trees.

Table 3. Recorded liveweight (mean \pm SD) of mature male and female goats in New South Wales and Queensland from 2012 to 2103

\begin{tabular}{|c|c|c|c|c|c|c|c|c|}
\hline & \multicolumn{3}{|c|}{ Pastoral regions } & \multirow[b]{2}{*}{ Subtotal } & \multicolumn{3}{|c|}{ High rainfall regions } & \multirow[b]{2}{*}{ Subtotal } \\
\hline & West & S.West & C.West & & East & S.East & North & \\
\hline Num & 9 & 3 & 5 & 17 & 9 & 4 & 1 & 14 \\
\hline Records available & 2 & 1 & 3 & 6 & 9 & 2 & 1 & 12 \\
\hline Liveweight for male $(\mathrm{kg})$ & $61 \pm 41$ & 50.0 & $60 \pm 28$ & $58 \pm 25$ & $104 \pm 13$ & $100 \pm 28$ & 80.0 & $101 \pm 15$ \\
\hline Liveweight for female $(\mathrm{kg})$ & $42 \pm 17$ & 40.0 & $50 \pm 14$ & $45 \pm 12$ & $73 \pm 9$ & $65 \pm 21$ & 60.0 & $71 \pm 11$ \\
\hline
\end{tabular}




\section{Breeding season}

Goat producers were asked if they saw a natural breeding season in the goat herd. Most of the producers $(87 \%, 27 / 31)$ identified a natural breeding season in goats to occur between December and May, and the non-breeding season between June and December (Fig. 2). The landholders also reported that does start showing oestrus and conceiving within a short interval after rainfall that is sufficient to facilitate pasture growth in October and November. One producer also mentioned that his goats did not have a breeding season on his property.

Only the stud breeders $(45 \% ; 14 / 31)$ reported a controlled mating season. These producers segregated female goats from bucks during the non-breeding season. A total of $71 \%(22 / 31)$ of producers reported that some animals within the herd (bucks, does or kids) were segregated from the rest of the herd, but did not specify the time of year when segregation occurred.

\begin{tabular}{|c|c|c|c|c|c|c|c|c|c|c|c|c|}
\hline \multirow[t]{2}{*}{ Survey regions } & \multicolumn{12}{|c|}{ Months } \\
\hline & J & $\mathrm{F}$ & $\mathrm{M}$ & A & $\mathrm{M}$ & $\mathrm{J}$ & $\mathrm{J}$ & A & $S$ & $\mathrm{O}$ & $\mathrm{N}$ & $\mathrm{D}$ \\
\hline Far North, QLD & & & & & & & & & & & & \\
\hline Central-western, QLD & & & & & & & & & & & & \\
\hline South-western, QLD & & & & & & & & & & & & \\
\hline South-eastern, QLD & & & & & & & & & & & & \\
\hline Western, NSW & & & & & & & & & & & & \\
\hline Eastern, NSW & & & & & & & & & & & & \\
\hline
\end{tabular}

Fig. 2. Schematic distribution of the breeding season (gray squares) and non-breeding season (white squares) according to producer's perception.

\section{Liveweight and weight gain at weaning}

Birth weights of kids were less in the pastoral regions than the birth weights of kids in the high rainfall regions (Table 4). Overall, 61\% (19/31) of the surveyed producers weaned their goat kids. Although all the producers from high rainfall regions weaned the kids, none of the producers from south-western QLD and only 22\% (2/9) of producers from western NSW weaned their kids. A total of 52\% (16/31) of producers castrated male kids between three and four months of age (Table 4). On average, the reported weaning age varied from three to six months and weaning weight varied from $17 \mathrm{~kg}$ to $25 \mathrm{~kg}$. Although weaning weights were similar between regions, the age of the kids at weaning was greater for the pastoral regions at 4.5 months compared to the high rainfall regions 
of 3.2 months (Table 4). The pastoral and high rainfall regions targeted similar weaning live weights for kids at approximately $25 \mathrm{~kg}$. The calculated weight gain at weaning varied between regions, from $105 \mathrm{~g} /$ day in central-western QLD to $204 \mathrm{~g} /$ day in eastern NSW (Table 4). 
Table 4. Mean $( \pm$ SD) reported birth weight of kids, weaning weight, age at weaning, calculated and targeted weaning weights and age for castration of male goats in New South Wales and Queensland from 2012 to 2103

\begin{tabular}{|c|c|c|c|c|c|c|c|c|}
\hline & \multicolumn{3}{|c|}{ Pastoral regions } & \multirow[b]{2}{*}{ Subtotal } & \multicolumn{3}{|c|}{ High rainfall regions } & \multirow[b]{2}{*}{ Subtotal } \\
\hline & $\begin{array}{l}\text { West } \\
\text { NSW }\end{array}$ & $\begin{array}{l}\text { S.West } \\
\text { QLD* }\end{array}$ & $\begin{array}{l}\text { C.West } \\
\text { QLD }\end{array}$ & & $\begin{array}{l}\text { East } \\
\text { NSW }\end{array}$ & $\begin{array}{l}\text { S.East } \\
\text { QLD }\end{array}$ & $\begin{array}{l}\text { North } \\
\text { QLD }\end{array}$ & \\
\hline Number of properties & 9 & 3 & 5 & 17 & 9 & 4 & 1 & 14 \\
\hline Reported to wean the kids & 2 & 0 & 3 & 5 & 9 & 4 & 1 & 14 \\
\hline Records available (n) & 3 & 0 & 2 & 5 & 9 & 4 & 1 & 14 \\
\hline Birth weight $(\mathrm{kg})$ & $2.4 \pm 0.2$ & . & $2.3 \pm 0.3$ & $2.3 \pm 0.2$ & $3.5 \pm 0.5$ & $3.6 \pm 0.3$ & 3.5 & $3.5 \pm 0.4$ \\
\hline Liveweight at wean $(\mathrm{kg})$ & $20.5 \pm 4.9$ & . & $18.3 \pm 2.8$ & $19.6 \pm 3.2$ & $23.5 \pm 5.7$ & $20.7 \pm 6.5$ & 17.0 & $22 \pm 5.8$ \\
\hline Age at wean (month) & $4.2 \pm 1.4$ & . & $5.1 \pm 1.4$ & $4.5 \pm 1.3$ & $3.3 \pm 0.2$ & $3.4 \pm 0.2$ & 3.0 & $3.2 \pm 0.2$ \\
\hline $\begin{array}{l}\text { Calculated weight gain at } \\
\text { weaning (g/day) }\end{array}$ & 143.7 & . & 104.6 & 128.1 & 204.0 & 167.6 & 150.0 & 195.8 \\
\hline Target weaning weight $(\mathrm{kg})$ & $20.5 \pm 4.9$ & . & $27.5 \pm 5.6$ & $24 \pm 7.8$ & $28.1 \pm 4.1$ & $20.8 \pm 6.5$ & 20.0 & $25 \pm 6.1$ \\
\hline Producers who castrate (n) & 2 & . & 2 & 4 & 8 & 3 & 1 & 12 \\
\hline Castration age (month) & $3.5 \pm 0.7$ & . & $4.1 \pm 1.0$ & $3.3 \pm 1.3$ & $2.1 \pm 0.5$ & $3.5 \pm 2.5$ & 3.0 & $2.6 \pm 1.3$ \\
\hline
\end{tabular}

* There was no information available from producers from south-western QLD. 


\section{Reproductive performance}

Only 10\% (3/31) of producers reported that pregnancy diagnosis of their females was carried out by ultrasonography. The other $90 \%$ of producers either assessed the pregnancy status of a doe, usually in late pregnancy, by visual observation or did not assess the pregnancy status of their doe herd. Overall, 48\% (15/31) of producers mentioned they kept some form of reproductive performance records such as pregnancy rates, kidding rates, prolificacy and kidding interval. All the seedstock producers from high rainfall regions recorded reproductive data; in contrast, none of the producers from western NSW and south-western QLD recorded reproductive data (Table 5). The reported pregnancy rate was higher than 93\%, except for the producers from central-western QLD who reported a pregnancy rate of $60 \%$ and western NSW and south-western QLD who failed to report the pregnancy rate of their doe herd. Overall, producers reported that the kidding rate increased between a poor season and a good season. However, regardless of the seasonal conditions, the kidding rate and prolificacy was less in central-western QLD compared to the high rainfall regions. The average prolificacy was $0.9 \mathrm{kids} / \mathrm{doe}$ in centralwestern QLD compared to $1.6 \mathrm{kids} / \mathrm{doe}$ in the high rainfall regions. Most of producers reported a kidding interval of 12 months (Table 5). In addition, producers indicated that goats were very prolific, reporting the mean $( \pm S D)$ prolificacy rate for doe herds to be $65 \pm 14 \%$ twins, $13 \pm 8 \%$ triplets and $22 \pm 14 \%$ single bearing does.

Age at first mating for young does (maiden) was 8.5 months for the pastoral regions compared to the high rainfall regions where the mean age at first mating was 15.2 months. Forty-seven percent (8/17) of properties in the pastoral regions reported to retain an average of $50 \%$ of young does in the breeding herd compared to $34.6 \%$ of young does retained in the high rainfall regions (Table 6).

\section{Criteria for selecting Bucks}

Goat producers in the high rainfall regions selected bucks for two or more criteria. In contrast, the majority of producers in the pastoral regions selected bucks for two or less criteria (Table 7). The most common criterion for selecting bucks was conformation or absence of physical defects, reported by $80 \%$ (25/31) of surveyed producers. The selection criteria of weight for age, temperament and colour were used by $32 \%(10 / 31)$ of respondents when selecting bucks. Only two seedstock producers in the high rainfall regions used Kidplan® as a selection criterion for bucks (Table 7). 


\section{Reasons for culling Bucks and Does}

Mature does and bucks were culled when they were unproductive or over seven years old on $58 \%$ (18/31) of surveyed properties. Bucks were most likely to be culled because of physical defects (71\%) such as angulations of legs and dentition defects, old age $(58 \%)$, reproductive problems $(55 \%)$ and temperament $(45 \%)$. The main criteria for culling does were failure to become pregnant and deliver a kid (65\%), old age (58\%), mastitis (48\%) and failure to rear a kid (39\%).

Seedstock producers routinely culled their animals and they appeared to place emphasis on conformational traits $(93 \%, 13 / 14)$. For instance, in full blood Boer goats, the presence of two individual teats on each udder was acceptable; more than two teats on each udder was a major fault and the doe would be culled. However, producers dealing with opportunistic harvesting enterprises reported that they did not routinely cull their animals. They sold their animals in accordance with the international market specifications, usually when animals reached the minimum dressed carcass weight of 12 $\mathrm{kg}$. In contrast, seedstock producers normally culled Bucks and Does before 12 monthsof-age when animals presented with major physical defects or conformational faults. If young females (maidens) or does less than 2 years-of-age fail to deliver a kid, producers mentioned they normally rebred these animals, but if an adult doe, older than 2 years old, failed to deliver a kid, producers reported they were culled. In addition, they mentioned that wethers were culled between four and 12 months of age or when wethers achieved the best body weight for sale.

\section{Supplementary feeding}

All producers in the high rainfall regions reported using supplements in their goat herds compared to $41 \%$ (7/17) of producers from pastoral regions. A majority of producers from western NSW $(89 \%, 8 / 9)$ and south-western QLD $(67 \%, 2 / 3)$ did not use any supplements (Table 8). The most commonly used supplements were mixes or formulated rations $(48 \% ; 15 / 31)$ and feed blocks $(45 \% ; 14 / 31)$. Only producers in the high rainfall regions reported to use grain $(57 \%, 8 / 14)$ and crops $(36 \% ; 5 / 14)$. Only $13 \%$ $(4 / 31)$ of producers reported the use of rumen modifiers for their goat herd (Table 8$)$. The classes of goats fed with supplements in order of frequency were: does (68\%), kids (61\%) and bucks $(55 \%)$. 
Table 5. Mean $( \pm$ SD) for reported pregnancy and kidding rates, doe prolificacy and kidding interval in New South Wales and Queensland from 2012 to 2103

\begin{tabular}{|c|c|c|c|c|c|c|c|c|}
\hline & \multicolumn{3}{|c|}{ Pastoral regions } & \multirow[b]{2}{*}{ Subtotal } & \multicolumn{3}{|c|}{ High rainfall regions } & \multirow[b]{2}{*}{ Subtotal } \\
\hline & $\begin{array}{l}\text { West } \\
\text { NSW** }\end{array}$ & $\begin{array}{l}\text { S.West } \\
\text { QLD* }\end{array}$ & $\begin{array}{l}\text { C.West } \\
\text { QLD }\end{array}$ & & $\begin{array}{l}\text { East } \\
\text { NSW }\end{array}$ & $\begin{array}{l}\text { S.East } \\
\text { QLD }\end{array}$ & $\begin{array}{l}\text { North } \\
\text { QLD }\end{array}$ & \\
\hline Number of properties & 9 & 3 & 5 & 17 & 9 & 4 & 1 & 14 \\
\hline Records available & 0 & 0 & 1 & 1 & 9 & 4 & 1 & 14 \\
\hline Pregnancy rate $(\%)$ & • & - & 60 & 60 & $93 \pm 4$ & $95 \pm 4$ & 96 & $94.2 \pm 3.6$ \\
\hline \multicolumn{9}{|l|}{ Kidding rate: } \\
\hline Poor season $(\%)$ & & . & 60 & 60 & $153 \pm 58$ & $127 \pm 38$ & 100 & $142 \pm 52$ \\
\hline Average season (\%) & . & . & 85 & 85 & $171 \pm 66$ & $160 \pm 34$ & 150 & $166 \pm 55$ \\
\hline Good season $(\%)$ & . & . & 120 & 120 & $186 \pm 74$ & $202 \pm 33$ & 200 & $191 \pm 61$ \\
\hline Prolificacy (kids/doe) & . & . & 0.9 & 0.9 & $1.7 \pm 0.3$ & $1.6 \pm 0.4$ & 1.5 & $1.6 \pm 0.2$ \\
\hline Kidding interval (months) & . & . & 12 & 12 & $11.5 \pm 1.3$ & 12.0 & 12.0 & $11.7 \pm 1.1$ \\
\hline
\end{tabular}

* There was no information available from producers from western NSW and south-western QLD.

Table 6. Mean $( \pm \mathrm{SD})$ Age that young does enter the breeding season and age at first kidding in New South Wales and Queensland from 2012 to 2103

\begin{tabular}{lcccccccc}
\hline & \multicolumn{3}{c}{ Pastoral regions } & & \multicolumn{3}{c}{ High rainfall regions } \\
\cline { 2 - 5 } & West & S.West & C.West & Subtotal & East & S.East & North & Subtotal \\
& NSW & QLD & QLD & & & NSW & QLD & QLD \\
\hline Number of properties & 9 & 3 & 5 & 17 & 9 & 4 & 1 & 14 \\
Records available & 3 & 2 & 3 & 8 & 9 & 4 & 1 & 14 \\
Age at first mating (month) & $6 \pm 0.0$ & $8 \pm 2.8$ & $11.5 \pm 4.9$ & $8.5 \pm 3.5$ & $15 \pm 3.3$ & $16.5 \pm 3.0$ & 12.0 & $15.2 \pm 3.1$ \\
Age at first kid (month) & $11 \pm 0.0$ & $13 \pm 2.8$ & $16.5 \pm 2.5$ & $14.1 \pm 3.1$ & $20.3 \pm 3.4$ & $21.5 \pm 3.0$ & 17.0 & $20.7 \pm 3.3$ \\
Retained young does (\%) & $33.3 \pm 15.3$ & $50.0 \pm 3$ & $62.5 \pm 18$ & $50 \pm 21$ & $42.7 \pm 33$ & $20 \pm 4.1$ & 20.0 & $34.6 \pm 28$ \\
\hline
\end{tabular}


Table 7. Criteria for selecting the bucks in the herd in New South Wales and Queensland from 2012 to 2103

\begin{tabular}{|c|c|c|c|c|c|c|c|c|c|}
\hline & \multicolumn{3}{|c|}{ Pastoral regions } & \multirow[b]{2}{*}{$\begin{array}{c}\text { Subtotal } \\
\mathrm{n}\end{array}$} & \multicolumn{3}{|c|}{ High rainfall regions } & \multirow[b]{2}{*}{$\begin{array}{c}\text { Subtotal } \\
\mathrm{n}\end{array}$} & \multirow[b]{2}{*}{$\begin{array}{c}\text { Overall } \\
\mathrm{n}(\%)\end{array}$} \\
\hline & $\begin{array}{l}\text { West } \\
\text { NSW }\end{array}$ & $\begin{array}{c}\text { S.West } \\
\text { QLD }\end{array}$ & $\begin{array}{l}\text { C.West } \\
\text { QLD }\end{array}$ & & $\begin{array}{l}\text { East } \\
\text { NSW }\end{array}$ & $\begin{array}{l}\text { S.East } \\
\text { QLD }\end{array}$ & $\begin{array}{l}\text { North } \\
\text { QLD }\end{array}$ & & \\
\hline Number of criteria selected & 9 & 3 & 5 & 17 & 9 & 4 & 1 & 14 & $31(100)$ \\
\hline \multicolumn{10}{|c|}{ Number of properties } \\
\hline 0 criteria & 4 & 1 & 0 & 5 & 0 & 0 & 0 & 0 & 5 \\
\hline 1 type & 2 & 2 & 1 & 5 & 0 & 0 & 0 & 0 & 5 \\
\hline 2 types & 3 & 0 & 3 & 6 & 3 & 1 & 1 & 5 & 11 \\
\hline$\geq 3$ types & 0 & 0 & 1 & 1 & 6 & 3 & 0 & 9 & 10 \\
\hline \multicolumn{10}{|c|}{ Criteria for selection } \\
\hline Conformation & 5 & 2 & 4 & 11 & 9 & 4 & 1 & 14 & $25(80)$ \\
\hline Weight for age & 2 & 0 & 2 & 4 & 5 & 1 & 0 & 6 & $10(32)$ \\
\hline Temperament & 1 & 0 & 2 & 3 & 4 & 2 & 1 & 7 & $10(32)$ \\
\hline Colour & 0 & 0 & 2 & 2 & 5 & 3 & 0 & 8 & $10(32)$ \\
\hline Kidplan® & 0 & 0 & 0 & 0 & 1 & 1 & 0 & 2 & $2(6)$ \\
\hline
\end{tabular}


Table 8. Use of supplements and/or rumen modifiers associated with goat production reported from New South Wales and Queensland

\begin{tabular}{|c|c|c|c|c|c|c|c|c|c|}
\hline & \multicolumn{3}{|c|}{ Pastoral regions } & \multicolumn{4}{|c|}{ High rainfall regions } & \multirow[b]{2}{*}{$\begin{array}{c}\text { Subtotal } \\
\mathrm{n}\end{array}$} & \multirow[b]{2}{*}{$\begin{array}{c}\text { Overall } \\
\mathrm{n}(\%)\end{array}$} \\
\hline & $\begin{array}{l}\text { West } \\
\text { NSW }\end{array}$ & $\begin{array}{l}\text { S.West } \\
\text { QLD }\end{array}$ & $\begin{array}{l}\text { C.West } \\
\text { QLD }\end{array}$ & $\begin{array}{c}\text { Subtotal } \\
\mathrm{n}\end{array}$ & $\begin{array}{l}\text { East } \\
\text { NSW }\end{array}$ & $\begin{array}{l}\text { S.East } \\
\text { QLD }\end{array}$ & $\begin{array}{l}\text { North } \\
\text { QLD }\end{array}$ & & \\
\hline Number of properties & 9 & 3 & 5 & 17 & 9 & 4 & 1 & 14 & $31(100)$ \\
\hline Producers using supplements & 1 & 1 & 5 & 7 & 9 & 4 & 1 & 14 & $21(68)$ \\
\hline $\begin{array}{l}\text { Producers using rumen } \\
\text { modifiers }\end{array}$ & 0 & 0 & 1 & 1 & 2 & 1 & 0 & 3 & $4(13)$ \\
\hline \multicolumn{10}{|c|}{ Type of supplements } \\
\hline Mixes (formulated ration) & 0 & 1 & 3 & 4 & 8 & 2 & 1 & 11 & $15(48)$ \\
\hline Feed blocks & 1 & 1 & 3 & 5 & 6 & 3 & 0 & 9 & $14(45)$ \\
\hline Grain & 0 & 0 & 0 & 0 & 6 & 2 & 0 & 8 & $8(26)$ \\
\hline Urea and associations & 0 & 0 & 2 & 2 & 0 & 2 & 2 & 4 & $6(19)$ \\
\hline Crops & 0 & 0 & 0 & 0 & 3 & 2 & 0 & 5 & $5(16)$ \\
\hline Whole cottonseed & 0 & 0 & 2 & 2 & 0 & 1 & 0 & 1 & $3(10)$ \\
\hline Protein meal (Copra) & 0 & 0 & 0 & 0 & 2 & 1 & 0 & 3 & $3(10)$ \\
\hline Phosphorus (P) only & 1 & 0 & 1 & 2 & 1 & 0 & 0 & 1 & $3(10)$ \\
\hline Protein meal (Soy bean) & 0 & 0 & 0 & 0 & 0 & 0 & 1 & 1 & $1(3)$ \\
\hline
\end{tabular}




\section{Animal Health}

In general, producers had limited data about goat herd health. They rarely used any diagnostic tests or any professional help to diagnose diseases. The producers who reported using faecal egg counts (FEC) as a tool to monitor the incidence and severity of gastrointestinal nematodes were predominately from high rainfall regions, accounting for $42 \%(13 / 31)$ of surveyed producers.

Gastrointestinal parasites were reported as a disease of concern by $100 \%$ of producers located in the high rainfall regions and by $29 \%(5 / 17)$ of producers in the pastoral regions. Producers from all regions reported the following diseases associated with their goat herds in order of importance: external parasites such as body lice (48\%, $15 / 31)$, caseous lymphadenitis $(26 \%, 8 / 31)$, contagious ecthyma $(10 \%, 3 / 31)$ and caprine arthritis encephalitis virus $(6 \%, 2 / 31)$. Only producers from high rainfall regions reported the occurrence of coccidiosis $(64 \%, 9 / 14)$ and enterotoxaemia $(43 \%, 6 / 14)$.

Although producers ranked gastrointestinal parasites and body lice as the most important diseases, only $52 \%(16 / 31)$ of producers reported drenching the animals with anthelmintics and only $48 \%(15 / 31)$ were controlling lice. Half of the properties $(7 / 14)$ from the high rainfall regions reported using greater than seven anthelmintic drugs (Table 9). However, producers from western NSW and south-western QLD reportedly had not used any anthelmintics in the previous three years to 2013 (Table 9). During inspection of the goat herd of three properties $(27 \%, 3 / 11)$ located in western NSW and southwestern QLD, the authors observed varying degrees of anaemia. These producers reported the anaemia to be caused by malnutrition rather than by internal parasite burden.

The chemical group macrocyclic lactones was the most commonly reported (52\%, 16/31) anthelmintic group used to treat goats for intestinal parasites (Table 9). To reduce the frequency of anthelmintic administration, 22\% (7/31) of producers were using the FAMACHA $^{\odot}$ system to monitor the colour of the eyelid for signs of anaemia. 
Table 9. Type of drenches (deworming products) used in New South Wales and Queensland in the previous three years to 2013

\begin{tabular}{|c|c|c|c|c|c|c|c|c|c|}
\hline & \multicolumn{3}{|c|}{ Pastoral regions } & \multirow[b]{2}{*}{$\begin{array}{c}\text { Subtotal } \\
\mathrm{n}\end{array}$} & \multicolumn{3}{|c|}{ High rainfall regions } & \multirow[b]{2}{*}{$\begin{array}{c}\text { Subtotal } \\
\mathrm{n}\end{array}$} & \multirow[b]{2}{*}{$\begin{array}{c}\text { Overall } \\
\mathrm{n}(\%)\end{array}$} \\
\hline & $\begin{array}{l}\text { West } \\
\text { NSW }\end{array}$ & $\begin{array}{c}\text { S.West } \\
\text { QLD }\end{array}$ & $\begin{array}{l}\text { C.West } \\
\text { QLD }\end{array}$ & & $\begin{array}{l}\text { East } \\
\text { NSW }\end{array}$ & $\begin{array}{l}\text { S.East } \\
\text { QLD }\end{array}$ & $\begin{array}{l}\text { North } \\
\text { QLD }\end{array}$ & & \\
\hline Number of chemical used & 9 & 3 & 5 & & 9 & 4 & 1 & & $31(100)$ \\
\hline \multicolumn{10}{|c|}{ Number of properties } \\
\hline 0 chemical & 9 & 3 & 3 & 15 & 0 & 0 & 0 & 0 & 15 \\
\hline 1 or 2 types & 0 & 0 & 1 & 1 & 0 & 0 & 0 & 0 & 1 \\
\hline 3 or 4 types & 0 & 0 & 1 & 1 & 1 & 2 & 0 & 3 & 4 \\
\hline 5 or 6 types & 0 & 0 & 0 & 0 & 3 & 1 & 0 & 4 & 4 \\
\hline$\geq 7$ types & 0 & 0 & 0 & 0 & 5 & 1 & 1 & 7 & 7 \\
\hline \multicolumn{10}{|c|}{ Anthelmintic groups used } \\
\hline Macrocyclic lactones ${ }^{1}$ & 0 & 0 & 2 & 2 & 9 & 4 & 1 & 14 & $16(52)$ \\
\hline Benzimidazoles $^{2}$ & 0 & 0 & 1 & 1 & 9 & 3 & 1 & 13 & $14(45)$ \\
\hline Nicotinic $^{3}$ & 0 & 0 & 1 & 1 & 9 & 4 & 0 & 13 & $14(45)$ \\
\hline Salicylanilides ${ }^{4}$ & 0 & 0 & 0 & 0 & 8 & 2 & 1 & 11 & $11(35)$ \\
\hline Amino acetonitrile ${ }^{5}$ & 0 & 0 & 0 & 0 & 5 & 1 & 1 & 7 & $7(23)$ \\
\hline Organophosphate & 0 & 0 & 0 & 0 & 0 & 0 & 1 & 1 & $1(3)$ \\
\hline
\end{tabular}

1 Abemectin, ivermectin, doramectin and moxidectin

${ }^{2}$ Albendazole, fenbendazole and oxfendazole

${ }^{3}$ Levamisole and Morantel

${ }^{4}$ Closantel

${ }^{5}$ Monepantel 
A total of $65 \%(20 / 31)$ of producers reported that they isolated sick animals and $45 \%(14 / 31)$ had a quarantine period for new animals. Seedstock producers from southeastern QLD and northern QLD said they did not have a quarantine period because they seldom introduce new animals, but they were willing to segregate new animals before introduction to the goat herd.

The vaccinations used in the goat herd were against clostridial diseases, being used by $52 \%(16 / 31)$ of producers, and vaccination against caseous lymphadenitis (13\%), normally, included with the clostridial vaccination pack (5 in 1). All the seedstock producers from high rainfall regions vaccinated their goat herd, but only two producers from pastoral regions vaccinated their goats

Mortality rates for kids ( 0 to 3 months), young goats (4 to 12 months) and adults (>12 months) are reported in Table 10. The mortality rate of the kids for western NSW and south-western QLD were unknown to producers interviewed. Central-western QLD presented greater mortality rate for kids at 33\%/year than the high rainfall regions at $12 \% / y e a r$. Mortality rates were also greater in young goats and adults in the pastoral regions compared to the high rainfall regions (Table 10). Producers from pastoral regions reported that the most common causes for mortality in goat herds were: starvation (malnutrition), dehydration, predators and old age.

Table 10. Mean ( \pm SD) reported annual mortality rates for kids, young goats and adult goats in New South Wales and Queensland from 2012 to 2013

\begin{tabular}{|c|c|c|c|c|c|c|c|c|}
\hline & \multicolumn{3}{|c|}{ Pastoral regions } & \multirow[b]{2}{*}{ Subtotal } & \multicolumn{3}{|c|}{ High rainfall regions } & \multirow[b]{2}{*}{ Subtotal } \\
\hline & $\begin{array}{c}\text { West } \\
\text { NSW* }^{*}\end{array}$ & $\begin{array}{l}\text { S.West } \\
\text { QLD* }\end{array}$ & $\begin{array}{l}\text { C.West } \\
\text { QLD }\end{array}$ & & $\begin{array}{c}\text { East } \\
\text { NSW }\end{array}$ & $\begin{array}{c}\text { S.East } \\
\text { QLD }\end{array}$ & $\begin{array}{l}\text { North } \\
\text { QLD }\end{array}$ & \\
\hline Number of properties & 9 & 3 & 5 & 17 & 9 & 4 & 1 & 14 \\
\hline Records available & 0 & 0 & 3 & 3 & 9 & 3 & 1 & 14 \\
\hline Mortality for kids (\%) & . & . & $33.3 \pm 23$ & $33.3 \pm 23$ & $12.5 \pm 11$ & $10.3 \pm 5$ & 5.0 & $11.6 \pm 9.9$ \\
\hline Mortality for young (\%) & . & . & $15.7 \pm 17$ & $15.7 \pm 17$ & $4 \pm 3$ & $9.0 \pm 7$ & 15.0 & $6.0 \pm 5.1$ \\
\hline Mortality for adults (\%) & . & . & $8.3 \pm 3$ & $8.3 \pm 3$ & $1.2 \pm 0.4$ & $7.0 \pm 7$ & 1.0 & $2.5 \pm 3.8$ \\
\hline
\end{tabular}

* There was no information on mortality in western NSW and south-western QLD.

When producers were asked about problems caused by feral animals and/or predators, the majority indicated that foxes $(65 \%)$, kangaroos $(52 \%)$, wild dogs (48\%) and feral pigs (48\%) were the biggest problem (Table 11). Wild dogs (including dingoes and dingo-crosses) were mentioned by properties in all regions, except for eastern NSW. Some producers used Maremma guardian dogs and traps to protect goat herds against wild dogs. 
Table 11. Problem caused by the following pests and/or predators in New South Wales and Queensland from 2012 to 2103

\begin{tabular}{|c|c|c|c|c|c|c|c|c|c|}
\hline \multirow[b]{2}{*}{ Pest or Predators } & \multicolumn{3}{|c|}{ Pastoral regions } & \multirow[b]{2}{*}{$\begin{array}{c}\text { Subtotal } \\
\mathrm{n}\end{array}$} & \multicolumn{3}{|c|}{ High rainfall regions } & \multirow[b]{2}{*}{$\begin{array}{c}\text { Subtotal } \\
\mathrm{n}\end{array}$} & \multirow[b]{2}{*}{$\begin{array}{c}\text { Overall } \\
\mathrm{n}(\%)\end{array}$} \\
\hline & $\begin{array}{l}\text { West } \\
\text { NSW }\end{array}$ & $\begin{array}{c}\text { S.West } \\
\text { QLD }\end{array}$ & $\begin{array}{l}\text { C.West } \\
\text { QLD }\end{array}$ & & $\begin{array}{c}\text { East } \\
\text { NSW }\end{array}$ & $\begin{array}{l}\text { S.East } \\
\text { QLD }\end{array}$ & $\begin{array}{l}\text { North } \\
\text { QLD }\end{array}$ & & \\
\hline Number of properties & \multicolumn{8}{|c|}{ Predators } & $31(100)$ \\
\hline Foxes & 5 & 1 & 2 & 8 & 9 & 3 & 0 & 12 & $20(65)$ \\
\hline Wild dogs & 2 & 3 & 5 & 10 & 0 & 4 & 1 & 5 & $15(48)$ \\
\hline Feral Pigs & 6 & 3 & 5 & 14 & 0 & 0 & 1 & 1 & $15(48)$ \\
\hline \multicolumn{10}{|c|}{ Non-predators } \\
\hline Kangaroos & 9 & 2 & 4 & 15 & 1 & 0 & 0 & 1 & $16(52)$ \\
\hline Rabbits & 3 & 0 & 0 & 3 & 7 & 4 & 0 & 11 & $14(45)$ \\
\hline Feral cats & 1 & 1 & 2 & 4 & 0 & 1 & 0 & 1 & $5(16)$ \\
\hline
\end{tabular}




\section{Discussion}

The properties located in the pastoral regions covered larger areas and the greatest number of goats per property, and represented $55 \%$ of producers involved in 'opportunistic harvesting' and commercial goat operations. On the other hand, $45 \%$ of properties were located in the high rainfall regions and were represented by specialized seedstock producers (Nogueira et al., 2014). The survey revealed that most producers do not record detailed data relating to herd health and performance. This failure to record data was more common among opportunistic harvesters who managed large properties in excess of 10,000 ha. Only seedstock producers who farmed smaller land areas were more commonly able to provide detailed herd performance data.

\section{Breeding season}

Only seedstock producers (45\%) from high rainfall regions were using a controlled mating season. These producers had smaller properties and goat herd size. In addition, they had better infrastructure, with holding paddocks, facilities to castrate wethers and the ability to segregate bucks during the non-breeding season.

In general, producers perceived that a natural breeding season in goats occurred from December to May (Fig. 2) and this is contrary to what Restall (1992) found in northeastern NSW $\left(29^{\circ} \mathrm{S}, 154^{\circ} \mathrm{E}\right)$ where only $30 \%$ of rangeland does began to ovulate between March-May. According to the same author, the highest incidence of ovulatory activity was detected between June-July with $60 \%$ of does ovulating during that period. The difference in the distribution of breeding season between our survey and Restall's (1992) findings may be due to differences in day length, temperature, rainfall, feed supply and the presence or absence of males (Mellado et al. 1991; Chemineau et al. 1992; WalkdenBrown and Bocquier 2000; Scaramuzzi and Martin 2008). Producers from centralwestern QLD and south-western QLD reported that goats started showing behavioural signs of oestrus in October and November (Fig. 2), after the onset of a period of rainfall. The natural increase in the plane of nutrition that occurs with the onset of rainfall and new pasture growth towards the end of the non-breeding season has been reported to stimulate the early onset of the breeding season in goats in Mexico and Australia (Mellado et al. 1991; Scaramuzzi and Martin 2008). The length of the breeding season was reported to be shortest in far north QLD which has the least variation in photoperiod. Freitas et al. (2004) reported that the duration of the breeding season is longer in tropical areas 
compared to more temperate regions of the world. This is in contrast to the findings of our survey, suggesting that there are local influences, including farmers' practices that result in variation in the breeding season.

\section{Goat breed}

Boer goats are used in many parts of the world to improve carcass weight (Van Niekerk and Casey 1988). However, producers from pastoral regions cited poor pregnancy rates and survival of Boer bucks as low in their environment. The reasons for the low pregnancy rates with Boer genotypes in some rangeland environments remain unclear from this survey. However, a number of reasons may be suggested. Firstly, there may be an underestimation of the ratio of Boer bucks to rangeland does and as a consequence competition from feral bucks for females may be greater than expected. Secondly, acclimatisation of Boer genotypes to pastoral browsing and climatic conditions may not have occurred, especially if death was the reported end result. Thirdly, insufficient supplementation and nutritional regimens of Boer goats in rangelands may be limiting their reproductive performance in the pastoral regions (MLA 2013).

\section{Liveweight and weight gain at weaning}

The greater liveweight of adult male and female goats in high rainfall regions can be explained by the dominance of Boer goats, which are heavier when compared to the rangeland goats raised in the pastoral regions. In addition, the pastoral regions rely heavily upon its natural resources as a feed base for livestock, including browse and native pasture species (Nogueira et al., 2014). In contrast, the high rainfall regions rely on improved pastures and supplementary feed (Table 8).

Breed and mature liveweight of goats have a major influence on other productive traits such as birth weight and weaning weight of the offspring, causing important impacts on animal production (McGregor and Butler 2010). Producers from the pastoral regions reported birth weights that were $1.2 \mathrm{~kg}$ less than those reported by producers in the high rainfall regions (Table 4). Eady and Rose (1988) reported similar birth weights to those given by producers in the pastoral regions for male $(2.76 \mathrm{~kg})$ and female $(2.54 \mathrm{~kg})$ cashmere kids in south-western QLD.

The results of weight gain at weaning varied from $104 \mathrm{~g} /$ day to $204 \mathrm{~g} / \mathrm{day}$ (Table 4). These variations can be explained by breed, sex, mature liveweight of does, production system (extensive or intensive) and the period of the year when kids were born (McGregor 
2005a). For instance, Boer goats raised in semi-intensive conditions can achieve a weaning weight gain of 169 g/day (Montaldo et al. 2010) and Boer goats crossed with rangeland goats in Australia achieved 148 g/day (Dhanda et al. 2003; McGregor 2005a). Furthermore, the reported growth rate at weaning of rangeland goats varied from $15 \mathrm{~g} /$ day to $82 \mathrm{~g} /$ day (McGregor et al. 1988) and the growth rate of Saanen wether goats fed with cows' milk ad libitum prior to weaning varied from 154 to 216 g/day (McGregor 1980), which is in accordance to the results from this survey.

Only $29 \%$ (5/17) of producers from pastoral regions reported to wean their kids (Table 4). One important explanation for the lack of strategic weaning is the lack of fencing or no fencing plans to create holding paddocks and to segregate the goat herd (Nogueira et al., 2014). Strategic weaning may confer production advantages to rangeland systems, with improvement in weaning weights and survival rates (McGregor and Butler 2010). Furthermore, strategic weaning can be used to reduce the loss of body condition in lactating does and to reduce the post-partum anoestrus interval (Freitas et al. 2004). By practicing early weaning producers can enter the premium domestic market in Australia, which requires goats to be sold at a dressed carcass weight of 6-12 kg, known as Capretto (Dhanda et al. 2003).

\section{Reproductive performance}

Little information was recorded by producers in the pastoral regions on reproductive parameters of their doe herds. In this survey, pregnancy rates were less in the pastoral region of central-western QLD (60\%) compared to the mean of the high rainfall regions (94\%; Table 5). The reported pregnancy rate from the pastoral region was represented by one producer and, therefore, caution should be taken in any interpretation of this difference. The lack of record keeping and herd management in the pastoral regions has cast a shadow over the true regional reproductive performance of the rangeland goat herd in Australia. However, better reproductive performance is possible in the pastoral zone. The current findings are different to Eady and Rose (1988) who reported a pregnancy rate of $89 \%$ in a controlled experimental goat herd in the pastoral region of south-western QLD. Similarly, Restall (1992) in north-eastern NSW observed a pregnancy rate of $88 \%$ on rangeland goats after an April joining. The ability of the animal to meet their nutrient requirements before and after mating, differences in day length, temperature, rainfall and the presence of fertile bucks are also important factors that affect 
ovulation and pregnancy rates in goats (Mellado et al. 1991; Chemineau et al. 1992; Walkden-Brown and Bocquier 2000; Martin et al. 2004; Scaramuzzi and Martin 2008).

The reported kidding rates varied by season. For all producers the kidding rates increased in a good season and decreased in a poor season (Table 5). Seasonal conditions and the quality of pasture can have significant impacts on liveweight and thus on pregnancy rate. In the rainy season the quality of pasture is better and as a consequence the goat herds have better reproductive performance (Nogueira et al. 2012). Prolificacy also varied between regions; for instance, the herd from the pastoral region of centralwestern QLD presented half of the prolificacy $(0.9 \mathrm{kids} / \mathrm{doe})$ of the herds in the high rainfall regions (1.6 kids/doe). These results may be explained by the feed base and the extensive management system of the pastoral regions, as Eady and Rose (1988) also reported a prolificacy of 1.6 kids per doe joined under a controlled experimental system.

The age at which maiden does are mated was reported to be less for the pastoral region (8.5 months) compared to the high rainfall region (15.2 months; Table 6). This may be explained by the lack of fencing and, therefore, this suggest a lack of control in the age at first mating for maiden does in the pastoral regions. Opportunistic harvesting operations will sell mature dry does to make up a consignment of animals that will meet a carcass weight specification (Nogueira et al., 2014). The practice of selling breeding animals may be why a greater percentage of young does are retained in the herds from the pastoral regions compared to the high rainfall regions.

\section{Criteria for selecting and reasons for culling bucks and does}

Only $6 \%$ of all producers reported using Kidplan ${ }^{\circledR}$ for the selection of breeding bucks (Table 7). Producers appeared to be unaware of the evaluations and positive outcomes from the use of Kidplan ${ }^{\circledR}$ as a selection tool. These results may also suggest that producers may be unwilling to use Kidplan ${ }^{\circledR}$ or that they do not see it as being economically worthwhile or necessary for the selection of bucks.

Seedstock producers routinely culled their animals and they appeared to place emphasis on conformational traits $(80 \%)$. In contrast, producers from pastoral regions did not routinely cull their animals, but they sold when animals achieved a target sale liveweight. Opportunistic harvesters removed their animals when they reach minimum sale weights and appeared to place little if any emphasis on other traits. This suggests that there is potential amongst opportunistic harvesters to improve productivity per head by applying selection criteria that remove unproductive or less productive animals from 
herds. It is known that regularly culling goats saves double handling and helps improve the productivity of the enterprise (MLA 2013).

\section{Supplementary feeding}

Feed availability and supplementary feeding in organized goat production may be one of the most important single factors that affect total productivity (Copland et al. 1984). Supplementary feeding was used by $100 \%$ of producers from high rainfall regions, but only $41 \%$ of producers from pastoral regions have used supplements to feed their goat herds (Table 8 ). These results can be explained by the difference in the animal production system (extensive or intensive). Supplementary feeding may not be available, difficult to provide or too expensive for goat producers in pastoral regions.

Furthermore, only $35 \%$ of producers evaluated body condition scores. This may suggest a lack of understanding on when supplementation may be required in the herds, as the use of body condition scoring accounts for $60-67 \%$ of the variation in liveweight change, carcass weight and fat reserves of goats (McGregor 2012). McGregor (2005b) reported that supplementation of goats is generally required during drought, and if this option is pursued, the best strategy is to provide supplementation early in a drought to finish and sell goats rather than holding them for an unknown period.

\section{Animal Heath}

The majority of producers from pastoral regions reported that gastrointestinal parasites were not a problem and that they never use any anthelmintic products. However, the authors observed varying degrees of anaemia in $27 \%$ of the goat herds inspected when undertaking this survey, suggesting that producers are unaware of the effect of gastrointestinal parasites. Further study is required to determine whether the anaemia in some animals was caused by malnutrition or caused by internal parasite burden with, for example, Haemonchus contortus.

Previous research has demonstrated that the $\mathrm{FAMACHA}^{\odot}$ system can be used to reduce indiscriminate use of drenches within sheep and goats (Kaplan et al. 2004; Reynecke et al. 2011). However, only $22 \%$ of respondents reported that they used the FAMACHA $^{\odot}$ system and $42 \%$ reported that they used FEC to monitor gastrointestinal parasite burdens. This may suggest that there is a greater need for goat herd managers to use monitoring tools when considering therapeutic treatments for gastrointestinal 
parasites. It may also suggest that producers are unaware of these tools or they do not see them as being necessary for management decisions.

A total of 13 anthelmintic products were reported by producers (Table 9). In Australia, most of the commercial anthelmintic products are not registered for goats and this is a problem mentioned by all surveyed producers. Chemicals that are widely used on sheep may be suitable for goats, but they need to go through the Australian processes of registration before dose rates and effectiveness can be verified for goats (Brice et al. 2012).

Coccidiosis, caseous lymphadenitis, enterotoxaemia, contagious ecthyma and caprine arthritis encephalitis appeared to be diseases more important in the high rainfall regions. This may be due to higher quality pastures associated with high stocking rates in the high rainfall regions (Nogueira et al., 2014), and high stocking rates may significantly increase the level of nematode infections (McGregor et al. 2014). The heavy reliance upon opportunistic goat harvesting operations in the pastoral regions may limit animal health monitoring and interventions. Further study will be needed to assess the true impact of these diseases in goat herds and whether implementing control measures is economically worthwhile and able to reduce the prevalence of these diseases, as well as, determining reasons for any perceived or real regional differences.

\section{Mortality rate and predators}

In the pastoral region of central-western QLD, the reported mortality rates for goat kids pre-weaning (33\%) and adults (8\%) were high (Table 10). It is likely that the mortality rate of kids may be greater than this as the western NSW and south-western QLD producers did not know the mortality rate of their kids. The mortality rate of goat kids from birth to weaning has been reported to be $15 \%$ in a controlled experimental herd in the pastoral region of south-western QLD (Eady and Rose 1988). Under a semiextensive production system, it was found that the mortality rate of crossbred AngloNubian goats varied from $12 \%$ to $23 \%$ for kids up to weaning and $5 \%$ to $13 \%$ for young goats (Nogueira et al. 2012). In high rainfall regions, the mortality rate for kids (11\%), young (6\%) and adult animals (2\%) was low, probably due to the better nutrition, animal health and less predators. However, on temperate pastures, mortality rate caused by internal parasitism can be increased by stocking rates equal or greater than 10 goat/ha (McGregor 2010). 
Predation of kids by wild dogs, foxes, wild pigs and wedge tailed eagles were reported as a significant source of losses for young goats from all producers. However, the numbers of kids that were predated upon in a year was unknown. Brice et al. (2012) reported that predators can affect a goat enterprise at any stage in the production cycle, but kids are the most vulnerable animals.

\section{Conclusions}

Rangeland goats represented $97 \%$ of the goat population covered in this survey. Producers who engage in opportunistic goat harvesting maintain few records related to herd management and animal health. On the other hand, commercial and seedstock producers generally keep more detailed records and are trying to improve the productivity of their goat herds. In general, properties in the pastoral regions showed low pregnancy and kidding rates, early age at first mating, high mortality rates, poor performance of Boer bucks and lower weights and weight gain than properties in the high rainfall regions. Few registered veterinary chemicals are available to control parasites of goats, and goat producers are using chemicals that are registered for use in sheep. The survey has highlighted areas that require further study to validate the observations of producers, for instance, factors that may be limiting the fertility of Boer goats in rangeland environments, the incidence of gastrointestinal parasites and infectious diseases, the use of Kidplan ${ }^{\circledR}$ and management strategies to improve goat productivity.

\section{Acknowledgments}

The authors gratefully acknowledge the support of James Cook University, Empresa Brasileira de Pesquisa Agropecuária (EMBRAPA) and Meat and Livestock Australia (MLA) for the conduct of this study. We thank the landholders who kindly received us on their properties and provided information and support for this study. The authors are also grateful for the useful comments and suggestions from the reviewers.

\section{References}

Ball, AJ, Brown, DJ, Spiker, SA, Field, SR, Banks, RB (2001) Opportunities for genetic development of the Boer Goat in Australia using Kidplan. Proceedings of the Association for the Advancement of Animal Breeding and Genetics 14, 445-448.

Batey, RG, Speed, CM, Kobes, CJ (1986) Prevalence and distribution of caseous lymphadenitis in feral goats. Australian Veterinary Journal 63, 33-36. 
Bortolussi, G, McEvoy, TG, Hodgkinson, J, Coffey, S, Holmes, CR (2005a) The 199697 CSIRO Northern Australian beef industry survey: methods and data classification. Australian Journal of Experimental Agriculture 60p.

Bortolussi, G, McIvor, JG, Hodgkinson, JJ, Coffey, SG, Holmes, CR (2005b) The northern Australian beef industry, a snapshot. 1. Regional enterprise activity and structure. Australian Journal of Experimental Agriculture 45, 1057-1073.

Boyazoglu, J, Hatziminaoglou, I, Morand-Fehr, P (2005) The role of the goat in society: Past, present and perspectives for the future. Small Ruminant Research 60, 13-23.

Brice, B, Day, P, Burgi, A (2012) Australian goat industry RD\&E strategy. Meat \& Livestock Australia Limited, Sydney, Australia. 1, 1-58.

Chemineau, P, Daveau, A, Maurice, F, Delgadillo, JA (1992) Seasonality of estrus and ovulation is not modified by subjecting female Alpine goats to a tropical photoperiod. Small Ruminant Research 8, 299-312.

Copland, J, Melendez, L, Talbot, R, Fernández, A, Teshe, R, Campos, H, Acha, P, Jones, M, Ferguson, G, Morales, H (1984) 'Goat production and research in the tropics, Proceedings of Workshop, University of Queensland, Brisbane, Australia.'

Dhanda, JS, Taylor, DG, Murray, PJ (2003) Part 1. Growth, carcass and meat quality parameters of male goats: effects of genotype and liveweight at slaughter. Small Ruminant Research 50, 57-66.

Eady, SJ, Rose, M (1988) Reproductive performance of Cashmere goats in south western Queensland. Proceedings of the Australian Society of Animal Production 17, 182185.

Ferrier, GR, McGregor, BA (2002) Benchmarks of Victorian commercial goat meat enterprises. Proceedings of the Australian Society of Animal Production 24, 6568.

Freitas, VJF, Rondina, D, Nogueira, DM, Simplício, AA (2004) Post-partum anoestrus in Anglo-Nubian and Saanen goats raised in semi-arid of North-eastern Brazil. Livestock Production Science 90, 219-226.

Greenwood, PL, North, RN, Kirkland, PD (1995) Prevalence, spread and control of caprine arthritis-encephalitis virus in dairy goat herds in New South Wales. Australian Veterinary Journal 72, 341-345.

IBRA (2014) Interim Biogeographic Regionalisation for Australia [Online]. Available at http://www.environment.gov.au/topics/land/national-reserve-system/sciencemaps-and-data/australias-bioregions-ibra (verified August 2014).

Kaplan, RM, Burke, JM, Terrill, TH, Miller, JE, Getz, WR, Mobini, S, Valencia, E, Williams, MJ, Williamson, LH, Larsen, M, Vatta, AF (2004) Validation of the FAMACHA(C) eye color chart for detecting clinical anemia in sheep and goats on farms in the southern United States. Veterinary Parasitology 123, 105-120.

Martin, GB, Rodger, J, Blache, D (2004) Nutritional and environmental effects on reproduction in small ruminants. Reproduction, Fertility and Development 16, 491-501.

McGregor, BA (1980) Growth and composition of wether goat carcass. Proceedings of the Australian Society of Animal Production 13, 345-348.

McGregor, BA (2005a) 'Compendium of growth rates of Australian goats.' (Department of Primary Industries: Attwood, Victoria)

McGregor, BA (2005b) Nutrition and Management of Goats in Drought. Rural Industries Research and Development Corporation 05/188, 1-90.

McGregor, BA (2010) Influence of stocking rate and mixed grazing of Angora goats and Merino sheep on animal and pasture production in southern Australia. 2. 
Liveweight, body condition score, carcass yield and mortality. Animal Production Science 50, 149-157.

McGregor, BA (2012) The role of objective and subjective evaluation in the production and marketing of goats for meat. Ch.8. In 'Goat Meat Production and Quality.' (Eds O Mahgoub, IT Kadim, EC Webb.) pp. 209-230. (CABI: Wallingford)

McGregor, BA, Butler, KL (2010) Relationship of weaning weight to the mature liveweight of cashmere does on Australian farms. Animal Production Science 50, 581-584.

McGregor, BA, Presidente, PJA, Campbell, NJ (2014) The influence of stocking rate and mixed grazing of Angora goats and Merino sheep on animal and pasture production in southern Australia. 4. Gastrointestinal parasitism. Animal Production Science 54, 587-597.

McGregor, BA, Wolde-Michael, T, Holmes, JHG (1988) The influence of energy supplementation and Zeranol implants on on growth and carcass characteristics of Australian feral goat kids. Proceedings of the Australian Society of Animal Production 17, 234-237.

McRae, T, Thomas, B (2014) Goat industry summary 2014. Meat and Livestock Australia Ltd. Available at http://www.mla.com.au/Prices-and-markets/Market-news/Goatindustry-summary-2014 (verified April 2014). 1, 17.

Mellado, M, Foote, RH, Gomez, A (1991) Reproductive efficiency of Nubian goats throughout the year in northern Mexico. Small Ruminant Research 6, 151-157.

MLA (2013) Meat and Livestock Australia. Going into Goats: A practical guide to producing goats in the rangelands [Online]. Available at http://www.rangelandgoats.com.au/home (verified June 2013). 147.

Montaldo, HH, Torres-Hernández, G, Valencia-Posadas, M (2010) Goat breeding research in Mexico. Small Ruminant Research 89, 155-163.

Nogueira, DM, Parker, A, Voltolini, TV, Moraes, SA, Moreira, JN, Araújo, GGLd, Filho, CG (2012) Reproductive and Productive Performance of Crossbred Goats Submitted to three Matings in two Years Under an Agro-Ecological Production System in the Semi-Arid Region of Brazil. Journal of Animal Production Advances 2, 429-435.

O'Callaghan, MG (1989) Coccidia of domestic and feral goats in South Australia. Veterinary Parasitology 30, 267-272.

Pople, T, Froese, J (2012) Distribution, abundance and harvesting of feral goats in the Australian rangelands, 1984-2011. Final report to the ACRIS Management Committee. Department of Employment, Economic Development \& Innovation, Brisbane, Qld. 1, 1-59.

Restall, BJ (1992) Seasonal variation in reproductive activity in Australian goats. Animal reproduction science $\mathbf{2 7}$, 305-318.

Restall, BJ, Mitchell, TD, Holst, PJ, Pym, RA, Nicholls, PJ, Norton, BW, Davies, L (1982) Australian feral goat: basis for a new industry? . Proceedings of the Australian Society of Animal Production 14, 130-145.

Reynecke, DP, van Wyk, JA, Gummow, B, Dorny, P, Boomker, J (2011) Validation of the FAMACHA@ eye colour chart using sensitivity/specificity analysis on two South African sheep farms. Veterinary Parasitology 177, 203-211.

Scaramuzzi, RJ, Martin, GB (2008) The importance of interactions among nutrition, seasonality and socio-sexual factors in the development of hormone-free methods for controlling fertility. Reproduction in Domestic Animals 43, 129-136.

Uzal, FA, Kelly, WR, Parsons, PG (1998) Enterotoxaemia in goats in Australia. Australian Veterinary Journal 76, 543. 
Van Niekerk, WA, Casey, NH (1988) The Boer goat. II. Growth, nutrient requirements, carcass and meat quality. Small Ruminant Research 1, 355-368.

Walkden-Brown, S, Bocquier, F (2000) 'Nutritional regulation of reproduction in goats.'

Nogueira DM, Gardiner CP, Gummow B, Cavalieri J, Fitzpatrick LA, Parker AJ (2015) A Survey of the Queensland and New South Wales Meat Goat Industry. 1. General property information, goat and pasture management. Animal Production Science (Paper 1 under review). 